\title{
Contemporary Verse Drama
}

\author{
Haybat Abdul Samad \\ English Department, Faculty of Arts and Human Sciences \\ Lebanese University, Beirut, Lebanon
}

\begin{abstract}
:
The hundred years that passed between 1850 - the year in which Catalina, the first verse play of Henrick Ibsen was published - and 1950 - the year in which another verse play appeared, namely T.S. Eliot's The Cocktail Party, were very eventful in European drama. In those years, a completely new dramatic movement - the spread of naturalistic prose drama - came into play. On the other hand, verse drama in the twentieth century, and particularly in England and Ireland, came back into the popular theater. At the hands of W.B. Yeats, T.S. Eliot and Christopher Fry, in the main, the dramatists who constituted the chief revolt against naturalism, contemporary verse drama revived against the naturalistic definition of drama, which in a sense considers characterization and action the main ends of drama. The aim of the paper is to compare and contrast the two styles of drama using the criticism of contemporary verse dramatists. The paper delves into the ways these dramatists tried to make verse play and distinguish themselves from naturalists. It continues to prove their failure while showing discontinuity of verse plays' popularity in the temporary audience's mind. The question is whether verse dramatists succeeded in instilling a feeling of suspense and popularity in the inner recesses of the audience's hearts or not; in other words, can verse drama preserve its influence on the audience? The significance of this study is to prove that although the role of verse drama lasted for centuries, its presence nowadays is vanishing as it is losing its power of influence.
\end{abstract}

Keywords: Contemporary verse drama, mystification, naturalism, poetic drama, prose drama, religious plays, verse drama, and symbolism

Cite as: Abdul Samad, H. (2018). Contemporary Verse Drama. Arab World English Journal for Translation \& Literary Studies, 2 (2). DOI: http://dx.doi.org/10.24093/awejtls/vol2no2.8 